\title{
A Helicobacter hepaticus catalase mutant is hypersensitive to oxidative stress and suffers increased DNA damage
}

\author{
Yang Hong, Ge Wang and Robert J. Maier \\ Department of Microbiology, University of Georgia, Athens, GA 30602, USA
}

\begin{abstract}
Correspondence
Robert J. Maier

rmaier@uga.edu
\end{abstract}

Received 15 August 2006

Accepted 12 December 2006

\begin{abstract}
Catalase (KatA) is known to play an important role in oxidative stress resistance in many bacterial species and a homologue exists in Helicobacter hepaticus, a member of the enterohepatic Helicobacter species. Here, a katA mutant was constructed by insertional mutagenesis and its oxidative stress phenotype was investigated. Catalase activity was readily detected [196 units (mg protein crude cell extract) ${ }^{-1}$ ] in the wild-type, whereas the mutant strain was deficient in, but not devoid of, activity. In contrast, Helicobacter pylori katA strains lack detectable catalase activity and wild-type $H$. pylori generally contains higher specific activity than $H$. hepaticus. Wild-type $H$. hepaticus cells tolerated $6 \% \mathrm{O}_{2}$ for growth, whilst the katA mutant could not survive at this oxygen level. Even at the optimal $\mathrm{O}_{2}$ level, the growth of the $H$. hepaticus katA strain was severely inhibited, which is also in contrast to $H$. pylori kat $A$ strains. Wild-type $H$. hepaticus cells withstood exposure to $100 \mathrm{mM} \mathrm{H}_{2} \mathrm{O}_{2}$ but the katA mutant cells were killed by the same treatment. Wild-type cells suffered no significant DNA damage by $\mathrm{H}_{2} \mathrm{O}_{2}$ treatment (100 mM for $6 \mathrm{~min}$ ), whilst the same treatment resulted in severe DNA fragmentation in the katA mutant. Thus $H$. hepaticus KatA plays an important role as an antioxidant protein.
\end{abstract}

\section{INTRODUCTION}

As an oxidative stress reagent, $\mathrm{H}_{2} \mathrm{O}_{2}$ attacks key sites in proteins. Particularly vulnerable are $4 \mathrm{Fe}-4 \mathrm{~S}$ clusters associated with cysteinyl sulfurs and the sulfur of methionine residues. Moreover, $\mathrm{H}_{2} \mathrm{O}_{2}$ reacts with intracellular free iron via the Fenton reaction to produce a more damaging reactive oxygen species, the hydroxyl radical; this reactive species will damage many biomolecules, including DNA (Valko et al., 2005). Organisms express the ubiquitous enzyme catalase, which decomposes $\mathrm{H}_{2} \mathrm{O}_{2}$ into water and oxygen, thus protecting organisms from the damaging effects of accumulating $\mathrm{H}_{2} \mathrm{O}_{2}$.

Helicobacter hepaticus is a Gram-negative, microaerophilic bacterium that occurs naturally in many strains of inbred mice (Fox et al., 1994). Although H. hepaticus was first isolated from the mouse liver, it is consistently recovered from the intestinal tract and the primary site of colonization was shown to be the lower bowel of mice (Fox et al., 1994, 1996). Chronic infection with $H$. hepaticus causes heptic lesions and leads to the development of hepatocellular carcinoma (Solnick \& Schauer, 2001). H. hepaticusinfected mice currently serve as an ideal animal model to study the mechanisms involved in the pathogenesis of human diseases such as hepatocellular carcinoma and inflammatory bowel diseases. This bacterium has become a topic of increasing research effort and was the second Helicobacter species (after Helicobacter pylori) to have its genome sequenced (Suerbaum et al., 2003). Recent studies have revealed that $H$. pylori combats oxidative stress via a battery of diverse antioxidant systems that contribute to its long-term persistent infection in the host (Harris et al., 2003; Olczak et al., 2002; Seyler et al., 2001; Wang \& Maier, 2004). Some of these systems are mechanistically novel, whereas others (such as superoxide dismutase and catalase) have been described in a number of pathogens. However, little is known about the antioxidant systems in $H$. hepaticus, and only a few targeted mutant strains of $H$. hepaticus have been reported so far (Hong et al., 2006; Mehta et al., 2005; Young et al., 2004); none of these are in predicted enzymic oxidative stress-combating factors. As a first step towards understanding the antioxidant abilities and in particular the role of catalase in $H$. hepaticus, we constructed a gene-targeted $H$. hepaticus catalase mutant.

\section{METHODS}

Bacterial strains, culture and growth conditions. H. hepaticus type strain ATCC 51449 was used in this study. H. hepaticus was cultured on Brucella agar (BA; Difco) plates supplemented with $10 \%$ defibrinated sheep blood at $37{ }^{\circ} \mathrm{C}$ in an incubator. The optimal atmosphere used for growth was $1 \% \mathrm{O}_{2}, 5 \% \mathrm{CO}_{2}$, with the balance of the atmosphere composed of $\mathrm{N}_{2}$. Different oxygen levels (1, 3 and $6 \% \mathrm{O}_{2}$ ) were also applied in oxidative stress resistance assays as indicated. Chloramphenicol $\left(20 \mu \mathrm{g} \mathrm{ml}^{-1}\right)$ was added to the medium for culture of the $H$. hepaticus mutant. Escherichia coli was grown 
aerobically on Luria-Bertani plates supplemented with ampicillin $\left(100 \mu \mathrm{g} \mathrm{ml}^{-1}\right)$ or chloramphenicol $\left(50 \mu \mathrm{g} \mathrm{ml}^{-1}\right)$. The plates were incubated at $37{ }^{\circ} \mathrm{C}$ in air.

katA mutant construction. Based on the genome sequence of $H$. hepaticus, primers katAF (5'-GTTTTCCGCCTCTTTTTCGC-3') and katAR (5'-AACATCGCCTGTGAGACATTCAG-3') were used to amplify a $1200 \mathrm{bp}$ fragment; the amplicon was ligated directly into pGEM-T vector (Promega; linear DNA with a 3' T overhang) and the construct was used to transform E. coli $\mathrm{DH} 5 \alpha$ by electrotransformation. The cloned plasmid was then extracted from the culture using a Qiagen extraction kit, and a chloramphenicol-resistance cassette $\left(\mathrm{Cm}^{\mathrm{R}}\right)$ was inserted into the unique HindIII restriction site within the katA gene. The recombinant plasmid pGEMT : katA : Cm was then introduced into $H$. hepaticus by electrotransformation. Allelic exchange occurred, leading to the formation of the katA mutant strain. The mutant was selected on blood agar plates supplemented with chloramphenicol $\left(20 \mu \mathrm{g} \mathrm{ml}^{-1}\right)$. The mutant was verified by demonstrating the correct-sized insertion of the $\mathrm{Cm}^{\mathrm{R}}$ cassette (by PCR) within the katA gene.

Oxygen sensitivity assay. A suspension of katA mutant or wild-type cells $(0.1 \mathrm{ml})$ with an $\mathrm{OD}_{600}$ of 0.8 was evenly spread onto $\mathrm{BA}$ plates and incubated for $72 \mathrm{~h}$ under different $\mathrm{O}_{2}$ partial pressures $(1,3$ and $6 \%)$ previously set for the experiment. Cells from a whole plate were harvested by suspension in $1 \mathrm{ml}$ PBS and the $\mathrm{OD}_{600}$ was measured (or calculated from dilutions) as an indication of relative growth yield.

Sensitivity to $\mathrm{H}_{\mathbf{2}} \mathrm{O}_{2}$. Wild-type and katA: : Cm cells grown at $1 \% \mathrm{O}_{2}$ for $48 \mathrm{~h}$ were suspended in $\mathrm{PBS}$ and the $\mathrm{OD}_{600}$ was adjusted to 1.5 . To test sensitivity towards $\mathrm{H}_{2} \mathrm{O}_{2}, 200 \mu \mathrm{l}$ cell suspension was mixed with $1.8 \mathrm{ml} 100 \mathrm{mM} \mathrm{H} \mathrm{H}_{2} \mathrm{O}_{2}$, vortexed briefly and incubated at room temperature. Every $3 \mathrm{~min}, 0.1 \mathrm{ml}$ of the cell/ $\mathrm{H}_{2} \mathrm{O}_{2}$ mixture was removed and spread onto blood agar plates. The plates were then incubated under $1 \% \mathrm{O}_{2}$ at $37{ }^{\circ} \mathrm{C}$. As a control, $0.1 \mathrm{ml}$ of the cell suspension (without exposure to $\mathrm{H}_{2} \mathrm{O}_{2}$ ) was taken and processed in the same way. After $48 \mathrm{~h}$ incubation, cells from each plate were harvested and suspended in $2 \mathrm{ml}$ PBS buffer and the $\mathrm{OD}_{600}$ was recorded.

DNA fragmentation assay. Wild-type or katA mutant cells were harvested at the late exponential phase from BA plates and suspended in PBS at an $\mathrm{OD}_{600}$ of 0.5. Samples were treated with $100 \mathrm{mM} \mathrm{H}_{2} \mathrm{O}_{2}$ for 0,3 or $6 \mathrm{~min}$ as described above, and then processed for gel electrophoresis. For the preparation of samples, we followed a procedure described previously (Zirkle \& Krieg, 1996) with minor modifications. Briefly, $\mathrm{H}_{2} \mathrm{O}_{2}$-treated or untreated cells were washed, suspended in TE buffer ( $50 \mathrm{mM}$ Tris/ $\mathrm{HCl}, 5 \mathrm{mM}$ EDTA, pH 8.0) and mixed with $1.0 \%$ low-melting-point agarose. After solidification, the gel plugs were placed in a lysis solution containing $0.5 \%(\mathrm{w} / \mathrm{v})$ Sarkosyl and $0.5 \mathrm{mg}$ proteinase $\mathrm{K} \mathrm{ml}^{-1}$ and incubated overnight at room temperature. The gel plugs were then washed with cold TE buffer and submerged in a $0.8 \%$ regular agarose gel. Samples were then subjected to electrophoresis and the gel was stained with ethidium bromide $\left(0.5 \mu \mathrm{g} \mathrm{ml}^{-1}\right)$ and visualized under UV light.

Catalase activity assay. The catalase activity of cell extracts was determined quantitatively following a method described previously (Wang et al., 2004). Briefly, catalase activity was measured spectrophotometrically at $25^{\circ} \mathrm{C}$ by following the decrease in $A_{240}$ $\left(\varepsilon_{240}=43.48 \mathrm{M}^{-1} \mathrm{~cm}^{-1}\right)$ of $13 \mathrm{mM} \mathrm{H}_{2} \mathrm{O}_{2}$ in PBS. All assays were repeated to give 12 rate determinations for the first minute of reaction. One unit was defined as the amount of enzyme that catalysed the oxidation of $1 \mu \mathrm{mol} \mathrm{H}_{2} \mathrm{O}_{2} \min ^{-1}$ under the assay conditions.

\section{RESULTS}

\section{Construction of a $\boldsymbol{H}$. hepaticus catalase mutant}

In the published genome sequence of $H$. hepaticus (Suerbaum et al., 2003), HH0043 was annotated as the gene encoding catalase. The katA gene in the H. hepaticus genome was disrupted by insertion of a $\mathrm{Cm}^{\mathrm{R}}$ cassette (Wang \& Taylor, 1990) via allelic exchange. Transformant colonies were obtained by screening for colonies in a $1 \%$ $\mathrm{O}_{2}$ environment. To confirm the correct insertion of the antibiotic-resistance cassette within the katA gene, genomic DNA prepared from the mutant clone was used as template for PCR with the primer pair katAF/katAR (Fig. 1a). As shown in Fig. 1(b), PCR using wild-type DNA as template produced a product of $1.2 \mathrm{~kb}$, whereas the mutant genomic DNA gave rise to a PCR product of $2.0 \mathrm{~kb}$, indicating insertion of the $0.8 \mathrm{~kb} \mathrm{Cm}^{\mathrm{R}}$ cassette.

\section{Protein profile and catalase activity in cell extracts}

Protein profiles were examined after SDS-PAGE of the wild-type and katA mutant cell extracts; the results are shown in Fig. 2. A $55 \mathrm{kDa}$ protein band was present in the wild-type cells but lacking in the mutant cells. This protein was identified as catalase by direct $\mathrm{N}$-terminal sequencing of the protein band, confirming that the strain H. hepaticus ATCC $51449 \mathrm{katA}$ : : Cm was a true catalase mutant. Based on densitometric measurement of the protein bands on the gel, KatA was estimated to constitute $\sim 1 \%$ of the total protein of the cell.

Catalase activity was determined for the wild-type and katA mutant cell extracts. The wild-type cells exhibited a catalase activity of $196 \pm 14$ units [ $\mu \mathrm{mol} \mathrm{H}_{2} \mathrm{O}_{2} \min ^{-1}$ (mg total protein $)^{-1}$, mean $\pm S D$ from five replicates]. In contrast, the katA mutant cells lost most of their catalase activity. Nevertheless, the residual amount of activity $(23 \pm 3$ units, for five replicates) was significantly higher than the background, which comprised heat-treated cell extract.

\section{Sensitivity to oxidative stress}

We examined the sensitivity of the katA mutant to $\mathrm{O}_{2}$ by measuring growth under different $\mathrm{O}_{2}$ concentration conditions in comparison with the wild-type strain. As $H$. hepaticus does not usually form discrete individual colonies on plates, we measured the $\mathrm{OD}_{600}$ of the cell suspensions as an indication of relative growth yield (Fig. 3). Even at $1 \%$ partial $\mathrm{O}_{2}$ pressure, the mutant strain grew much slower than the wild-type. Whilst the wild-type could still grow at $6 \% \mathrm{O}_{2}$ (albeit at a slower rate than at $1 \% \mathrm{O}_{2}$ ), the katA mutant could not survive under this $\mathrm{O}_{2}$ condition. This result clearly demonstrated that the $H$. hepaticus katA mutant was hypersensitive to $\mathrm{O}_{2}$.

To examine sensitivity to $\mathrm{H}_{2} \mathrm{O}_{2}$, the wild-type and katA mutant cells were treated with $100 \mathrm{mM} \mathrm{H}_{2} \mathrm{O}_{2}$ and samples 
(a)

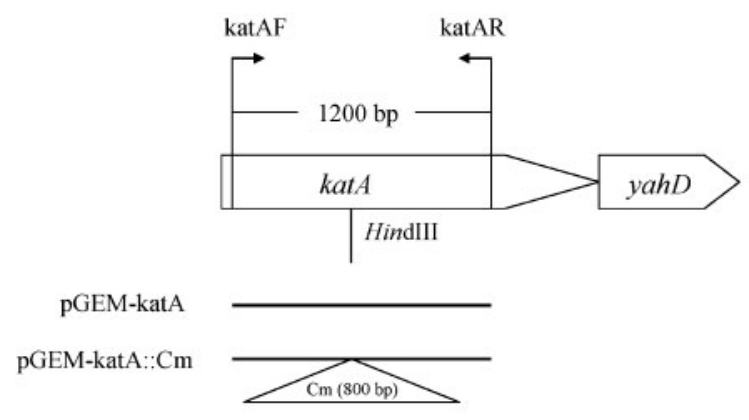

(b)

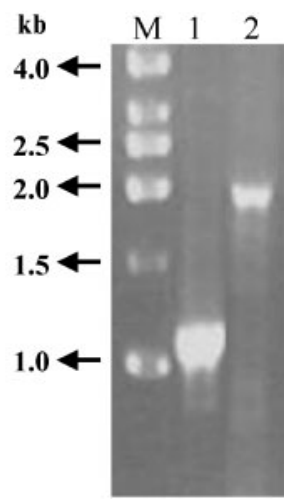

Fig. 1. (a) Organization of the katA gene in the $H$. hepaticus genome and DNA constructs for generating the kat $A$ mutant. $A$ $1200 \mathrm{bp}$ fragment of the $k a t A$ gene was amplified using the katAF/katAR primer pair and cloned into pGEM-T. A Cm ${ }^{R}$ cassette was then inserted within the katA fragment at the Hindlll restriction site and the plasmid pGEM-katA: :Cm was used for transformation of wild-type $H$. hepaticus to create the katA mutant. (b) Agarose gel analysis of PCR products using primers katAF/katAR. Lanes: 1 , wild-type $H$. hepaticus; 2 , katA mutant; M, DNA size standard.

were removed at $3 \mathrm{~min}$ intervals followed by transfer to normal growth conditions at $1 \% \mathrm{O}_{2}$. After incubating for $48 \mathrm{~h}$, the cells were collected in the same volume of PBS and $\mathrm{OD}_{600}$ was measured to represent the relative number of viable cells (Fig. 4). About half of the wild-type cells survived the initial 3 min treatment. Longer exposures to peroxide (up to $21 \mathrm{~min}$ ) did not significantly reduce cell viability further. In contrast, the majority of the katA mutant cells were killed by exposure to $\mathrm{H}_{2} \mathrm{O}_{2}$ for 3 min and no cells could be recovered after $\mathrm{H}_{2} \mathrm{O}_{2}$ treatment for 6 min.

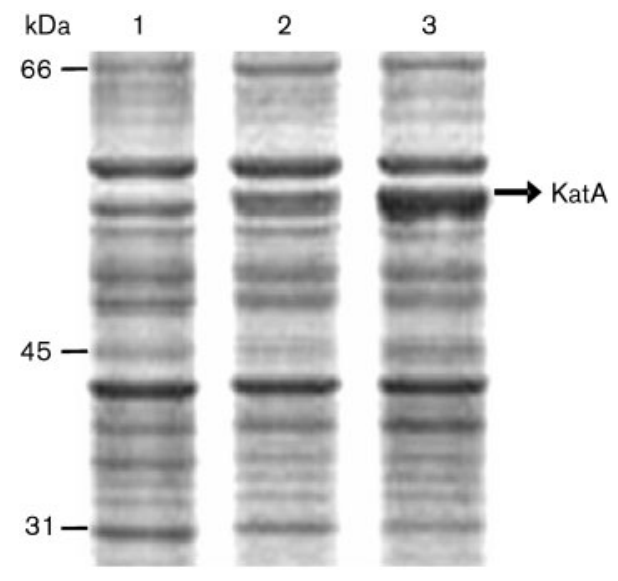

Fig. 2. Protein profiles of $H$. hepaticus cell crude extracts, analysed by SDS-PAGE. Seven micrograms of protein was loaded onto each lane. Lanes: 1, katA::Cm mutant; 2, wild-type cells; 3 , ahpC mutant (see Discussion). The sizes of protein markers are labelled on the left and the $55 \mathrm{kDa}$ KatA band is marked on the right.

\section{Level of DNA fragmentation}

To investigate the role of catalase in protecting DNA from damage, the level of DNA fragmentation was examined for the katA mutant strain in comparison with the wild type. Exponential phase growth cells were treated with $100 \mathrm{mM}$ $\mathrm{H}_{2} \mathrm{O}_{2}$ for 0,3 or 6 min and the samples were analysed for genomic DNA fragmentation by gel electrophoresis (Fig. 5). Little fragmented DNA was observed for the wild-type cells exposed to $\mathrm{H}_{2} \mathrm{O}_{2}$ for 3 or $6 \mathrm{~min}$. The katA mutant cells exposed to $\mathrm{H}_{2} \mathrm{O}_{2}$ for 3 min contained a small amount of fragmented DNA, and a large amount of the genomic DNA was damaged in the katA mutant cells exposed to $\mathrm{H}_{2} \mathrm{O}_{2}$ for 6 min.

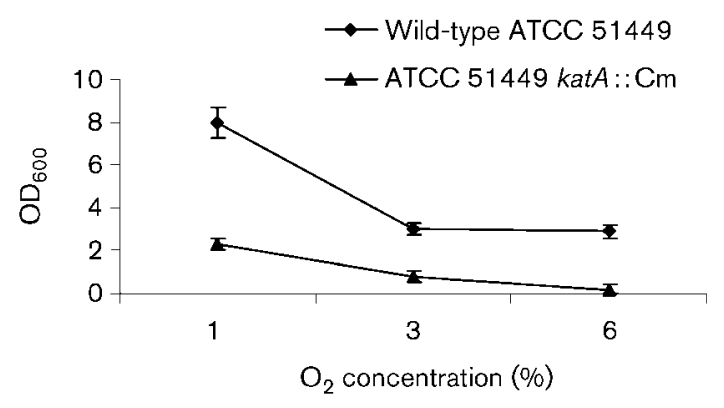

Fig. 3. Oxygen sensitivity of $H$. hepaticus strains. Cells were grown for $72 \mathrm{~h}$ under different $\mathrm{O}_{2}$ partial pressures (1, 3 and $6 \%$ ), harvested, suspended in PBS ( $1 \mathrm{ml}$ per plate) and the $\mathrm{OD}_{600}$ was measured. The results are the means $\pm S D$ of three experiments. According to the Student's $t$-test, the mutant grew significantly slower than the wild-type at the $99 \%$ level of confidence ( $P$ $<0.01$ ) at all of the $\mathrm{O}_{2}$ levels tested. 


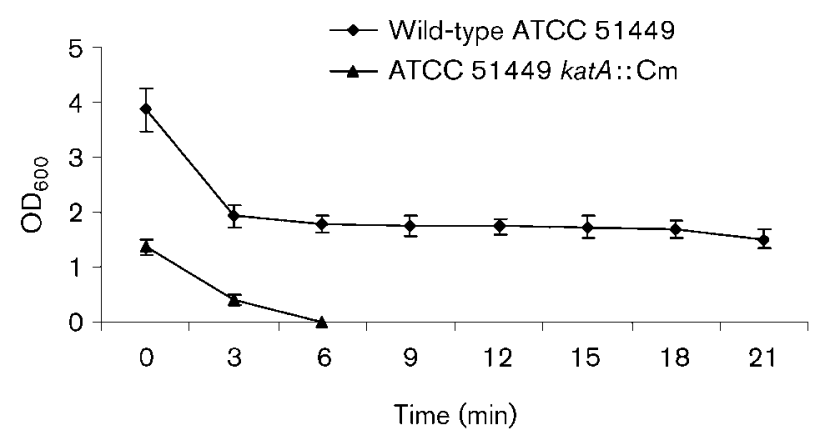

Fig. 4. Sensitivity of $H$. hepaticus wild-type and $k a t A:: C m$ strains to $100 \mathrm{mM} \mathrm{H}_{2} \mathrm{O}_{2}$ over a 21 min time period. The $y$-axis represents the relative number of cells surviving after exposure to $\mathrm{H}_{2} \mathrm{O}_{2}$. The results are the means \pm SD of three experiments and survival of the kat $A$ strain was significantly less than that of the wild-type at all points tested $(P<0.01)$.

\section{DISCUSSION}

H. hepaticus KatA is highly homologous to catalases in both prokaryotes and eukaryotes, with the highest homology being shown to the catalases of Bordetella pertussis $(65.9 \%)$ and $H$. pylori $(62.5 \%)$. The catalase activity in the cell extract of the wild-type strain ATCC 51449 was determined to be approximately 200 units $\left[\mu \mathrm{mol} \mathrm{H}_{2} \mathrm{O}_{2}\right.$ $\min ^{-1}$ (mg total protein $\left.)^{-1}\right]$. Using the same method, we examined different strains of $H$. pylori that usually express a high level of KatA protein $(>1 \%$ of the total protein) and the catalase activity ranged from approximately 1000 to 4000 units (unpublished data). One exception was $H$. pylori strain 26695, which expressed a very low amount of (a)

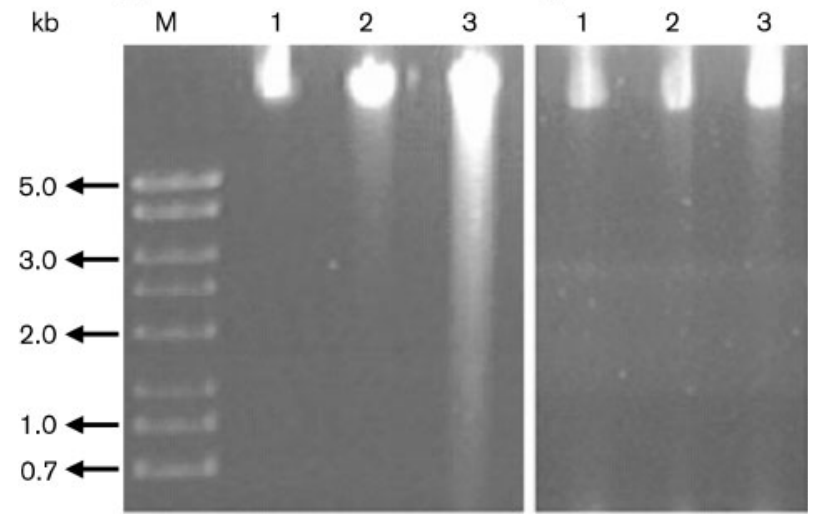

Fig. 5. DNA fragmentation assay. The katA mutant (a) or wild-type (b) cells were grown to late exponential phase, harvested in PBS buffer and exposed to $100 \mathrm{mM} \mathrm{H}_{2} \mathrm{O}_{2}$ for 0,3 or 6 min (lanes 1-3, respectively). The samples were processed for agarose gel electrophoresis to visualize the relative sizes of DNA fragments. A DNA size marker $(\mathrm{kb})$ is labelled on the left.
KatA protein and showed a catalase activity of $<400$ units. $H$. hepaticus also expressed a high level of KatA $(\sim 1 \%$ of the total protein, see Fig. 2a), but the specific activity of $H$. hepaticus KatA appears to be lower than that of $H$. pylori. It is possible that $H$. hepaticus encounters lower $\mathrm{H}_{2} \mathrm{O}_{2}$ levels than $H$. pylori in vivo.

Wild-type $H$. hepaticus cells were able to survive exposure to $100 \mathrm{mM} \mathrm{H}_{2} \mathrm{O}_{2}$, which is similar to results observed for H. pylori (Harris et al., 2002). For comparison, the $\mathrm{H}_{2} \mathrm{O}_{2}$ concentration used for sensitivity tests of Campylobacter is at a much lower level (1 mM) (Day et al., 2000; Grant \& Park, 1995). The ability of $H$. hepaticus cells to survive such high concentrations of $\mathrm{H}_{2} \mathrm{O}_{2}$ is indicative of the importance of catalase to the survival of the bacterium under oxidative stress conditions. Such stress conditions may result from the production of reactive oxygen species by the host cells following $H$. hepaticus infection. There is evidence that the levels of 8-oxo-guanine and lipid peroxidation are significantly higher in $H$. hepaticus-infected mice and that these oxidized macromolecules increase with duration of infection (Singh et al., 2001; Sipowicz et al., 1997). In addition, endogenous production of peroxides by $H$. hepaticus through auto-oxidation of flavoproteins could be a major source of oxidative stress (Imlay, 2003). Our recent studies on $H$. hepaticus alkyl hydroperoxide reductase (AhpC), the enzyme responsible for cell defence against organic peroxide oxidative stress, revealed that expression of KatA was greatly increased (Fig. 2a, lane 3) in $H$. hepaticus ahpC mutant cells as a compensatory response. This also highlights the importance of catalase in oxidative stress defence in $H$. hepaticus.

To define further the role of catalase in $H$. hepaticus, we examined the phenotypes of a katA mutant. The katA mutant cell extract had a minimal but detectable activity of $\mathrm{H}_{2} \mathrm{O}_{2}$ dissipation (about $1 / 10$ of the wild-type level). It is noteworthy that the katA mutants of $H$. pylori exhibit undetectable catalase activity (Harris et al., 2002; Odenbreit et al., 1996; Wang et al., 2004). The H. hepaticus genome sequence does not reveal the existence of another gene encoding a catalase or catalase-like protein. It is likely that the residual amount of activity detected in the katA mutant cell extract was due to the presence of other peroxidases (such as AhpC) that may have redundant $\mathrm{H}_{2} \mathrm{O}_{2}$ reducing activity.

Disruption of the katA gene rendered $H$. hepaticus cells hypersensitive to oxidative stress. Even under optimal growth conditions $\left(1 \% \mathrm{O}_{2}\right)$ for the wild-type, the mutant strain grew very poorly and it could not survive exposure to an atmosphere of $>6 \% \mathrm{O}_{2}$ (Fig. 3). Of note, H. pylori katA mutants are hypersensitive to $\mathrm{H}_{2} \mathrm{O}_{2}$, but grow similarly to the wild-type under optimal $\mathrm{O}_{2}$ conditions $\left(\begin{array}{lll}\sim & \% & \mathrm{O}_{2}\end{array}\right)$ (Harris et al., 2002; Odenbreit et al., 1996; Wang et al., 2004). The hypersensitivity of the H. hepaticus katA mutant to $\mathrm{H}_{2} \mathrm{O}_{2}$ (Fig. 4) provides evidence for the importance of catalase in the oxidative stress defence repertoire of $H$. hepaticus. 
As a powerful oxidant, $\mathrm{H}_{2} \mathrm{O}_{2}$ and its derivative hydroxyl radical can have a damaging effect on DNA. We determined the relative levels of DNA damage in $H$. hepaticus cells by use of a DNA fragmentation assay. Exposure to $\mathrm{H}_{2} \mathrm{O}_{2}$ for 6 min completely killed the katA mutant cells (Fig. 4), and the result in Fig. 5 showed that these cells contained a large amount of fragmented DNA. These results indicate the importance of KatA in protecting $H$. hepaticus from $\mathrm{H}_{2} \mathrm{O}_{2}$-mediated DNA damage.

Downstream of $H$. hepaticus katA is a gene (yahD) encoding an ankyrin-repeat protein of unknown function (Fig. 1a). Homologues of this gene are present in many pathogenic bacteria such as Campylobacter jejuni, Streptomyces avermitilis and Pseudomonas putida, but none of these have been studied. Downstream of katA in H. pylori is a gene named $k a p A$, which is not a homologue of $y a h D$. Disruption of kapA in $H$. pylori does not affect catalase activity, but nevertheless results in an increased sensitivity to $\mathrm{H}_{2} \mathrm{O}_{2}$ (Harris et al., 2002). H. pylori catalase has been shown to localize in both the cytoplasm and periplasm, and the catalase activity within the periplasm is significantly affected by the loss of KapA (Harris \& Hazell, 2003). Through interaction with KatA, KapA may be involved in the translocation of KatA into the periplasm. The effects of $H$. hepaticus yahD on catalase activity and $\mathrm{H}_{2} \mathrm{O}_{2}$ sensitivity need to be investigated, as one of the known roles of ankyrin-repeat proteins is mediating protein-protein interactions (Sedgwick \& Smerdon, 1999). Future studies including complementation of KatA function and the effect of KatA disruption on host colonization efficiency are required for a further understanding of the importance of catalase in $H$. hepaticus pathogenesis.

\section{ACKNOWLEDGEMENTS}

This work was supported by NIH grants DK60061 and DK62852 to R. J. M.

\section{REFERENCES}

Day, W. A., Jr, Sajecki, J. L., Pitts, T. M. \& Joens, L. A. (2000). Role of catalase in Campylobacter jejuni intracellular survival. Infect Immun 68, 6337-6345.

Fox, J. G., Dewhirst, F. E., Tully, J. G., Paster, B. J., Yan, L., Taylor, N. S., Collins, M. J., Jr, Gorelick, P. L. \& Ward, J. M. (1994). Helicobacter hepaticus sp. nov., a microaerophilic bacterium isolated from livers and intestinal mucosal scrapings from mice. J Clin Microbiol 32, 1238-1245.

Fox, J. G., Li, X., Yan, L., Cahill, R. J., Hurley, R., Lewis, R. \& Murphy, J. C. (1996). Chronic proliferative hepatitis in $\mathrm{A} / \mathrm{JCr}$ mice associated with persistent Helicobacter hepaticus infection: a model of helicobacter-induced carcinogenesis. Infect Immun 64, 1548-1558.

Grant, K. A. \& Park, S. F. (1995). Molecular characterization of katA from Campylobacter jejuni and generation of a catalase-deficient mutant of Campylobacter coli by interspecific allelic exchange. Microbiology 141, 1369-1376.

Harris, A. G. \& Hazell, S. L. (2003). Localisation of Helicobacter pylori catalase in both the periplasm and cytoplasm, and its dependence on the twin-arginine target protein, KapA, for activity. FEMS Microbiol Lett 229, 283-289.

Harris, A. G., Hinds, F. E., Beckhouse, A. G., Kolesnikow, T. \& Hazell, S. L. (2002). Resistance to hydrogen peroxide in Helicobacter pylori: role of catalase (KatA) and Fur, and functional analysis of a novel gene product designated 'KatA-associated protein', KapA (HP0874). Microbiology 148, 3813-3825.

Harris, A. G., Wilson, J. E., Danon, S. J., Dixon, M. F., Donegan, K. \& Hazell, S. L. (2003). Catalase (KatA) and KatA-associated protein (KapA) are essential to persistent colonization in the Helicobacter pylori SS1 mouse model. Microbiology 149, 665-672.

Hong, T., Wang, G. \& Maier, R. J. (2006). Helicobacter hepaticus Dps protein plays an important role in protecting DNA from oxidative damage. Free Radic Res 40, 597-605.

Imlay, J. A. (2003). Pathways of oxidative damage. Annu Rev Microbiol 57, 395-418.

Mehta, N., Benoit, S., Mysore, J. V., Sousa, R. S. \& Maier, R. J. (2005). Helicobacter hepaticus hydrogenase mutants are deficient in hydrogensupported amino acid uptake and in causing liver lesions in $\mathrm{A} / \mathrm{J}$ mice. Infect Immun 73, 5311-5318.

Odenbreit, S., Wieland, B. \& Haas, R. (1996). Cloning and genetic characterization of Helicobacter pylori catalase and construction of a catalase-deficient mutant strain. J Bacteriol 178, 6960-6967.

Olczak, A. A., Olson, J. W. \& Maier, R. J. (2002). Oxidative-stress resistance mutants of Helicobacter pylori. J Bacteriol 184, 3186-3193.

Sedgwick, S. G. \& Smerdon, S. J. (1999). The ankyrin repeat: a diversity of interactions on a common structural framework. Trends Biochem Sci 24, 311-316.

Seyler, R. W., Jr, Olson, J. W. \& Maier, R. J. (2001). Superoxide dismutase-deficient mutants of Helicobacter pylori are hypersensitive to oxidative stress and defective in host colonization. Infect Immun 69, 4034-4040.

Singh, R., Leuratti, C., Josyula, S., Sipowicz, M. A., Diwan, B. A., Kasprzak, K. S., Schut, H. A., Marnett, L. J., Anderson, L. M. \& Shuker, D. E. (2001). Lobe-specific increases in malondialdehyde DNA adduct formation in the livers of mice following infection with Helicobacter hepaticus. Carcinogenesis 22, 1281-1287.

Sipowicz, M. A., Chomarat, P., Diwan, B. A., Anver, M. A., Awasthi, Y. C., Ward, J. M., Rice, J. M., Kasprzak, K. S., Wild, C. P. \& Anderson, L. M. (1997). Increased oxidative DNA damage and hepatocyte overexpression of specific cytochrome P450 isoforms in hepatitis of mice infected with Helicobacter hepaticus. Am J Pathol 151, 933-941.

Solnick, J. V. \& Schauer, D. B. (2001). Emergence of diverse Helicobacter species in the pathogenesis of gastric and enterohepatic diseases. Clin Microbiol Rev 14, 59-97.

Suerbaum, S., Josenhans, C., Sterzenbach, T., Drescher, B., Brandt, P., Bell, M., Droge, M., Fartmann, B., Fischer, H. P. \& other authors (2003). The complete genome sequence of the carcinogenic bacterium Helicobacter hepaticus. Proc Natl Acad Sci U S A 100, 7901-7906.

Valko, M., Morris, H. \& Cronin, M. T. (2005). Metals, toxicity and oxidative stress. Curr Med Chem 12, 1161-1208.

Wang, G. \& Maier, R. J. (2004). An NADPH quinone reductase of Helicobacter pylori plays an important role in oxidative stress resistance and host colonization. Infect Immun 72, 1391-1396.

Wang, Y. \& Taylor, D. E. (1990). Chloramphenicol resistance in Campylobacter coli: nucleotide sequence, expression, and cloning vector construction. Gene 94, 23-28.

Wang, G., Conover, R. C., Benoit, S., Olczak, A. A., Olson, J. W., Johnson, M. K. \& Maier, R. J. (2004). Role of a bacterial organic hydroperoxide detoxification system in preventing catalase inactivation. J Biol Chem 279, 51908-51914. 
Young, V. B., Knox, K. A., Pratt, J. S., Cortez, J. S., Mansfield, L. S., Rogers, A. B., Fox, J. G. \& Schauer, D. B. (2004). In vitro and in vivo characterization of Helicobacter hepaticus cytolethal distending toxin mutants. Infect Immun 72, 2521-2527.
Zirkle, R. E. \& Krieg, N. R. (1996). Development of a method based on alkaline gel electrophoresis for estimation of oxidative damage to DNA in Escherichia coli. J Appl Bacteriol 81, $133-138$. 